Bangladesh J. Zool. 48(2): 215-230, 2020

ISSN: 0304-9027

eISSN: $2408-8455$

\title{
ICHTHYODIVERSITY OF THE FIVE LINKED RIVERS OF CHATTOGRAM BANGLADESH
}

\author{
M.A. Azadi ${ }^{* 1}$ and Mohammad Arshad-U1-Alam² \\ International Islamic University Chittagong, Kumira, Chattogram 4318 \\ Bangladesh
}

\begin{abstract}
Faunal records are essential to understand, manage and conserve any ecosystem if altered due to anthropogenic or natural causes. In the south eastern Bangladesh five linked rivers, Karnaphuli, Halda, Sikalbaha, Chandkhali and Sangu play a significant role in the country's fisheries sector. In this study ichthyofauna of the three linked rivers, Karnaphuli, Shikalbaha and Chandkhali are presented. From these three important linked rivers a total of 130 ichthyofaunal species, of which 112 finfish and 18 shellfish species were recorded during May 2010 to February 2020. Out of 130 species of finfish and shellfish, 128 species (110 fin and 18 shell fish) from the River Karnaphuli, 85 species (74 fin and 11 shell fish) from the River Shikalbaha and 83 species (72 fin and 11 shell fish) from the River Chandkhali were recorded. A total of 112 finfish species including four exotics belonged to 20 orders, 47 families, and 90 genera and 18 shellfish species were under one order, 3 families and 7 genera. Maximum finfish and shellfish species were under the families Cyprinidae (22 species) and Palaemonidae (9). Amongst the 112 finfish, one was critically endangered, six endangered and eleven was vulnerable. Systematic list of the ichthyofauna with local names is given. Status of local availability of species along with those reported as data deficient and not reported by IUCN (2015) are also provided. This study will help the fishery scientists, policy makers and planners to manage and conserve the fish faunal diversity in the three important linked rivers of Chattogram.
\end{abstract}

Key words: Ichthyofauna, Karnaphuli River, Sikalbaha River, Chandkhali River, finfish, shellfish, Chattogram.

\section{INTRODUCTION}

The trans boundary River Karnaphuli $\left(22^{\circ} 12^{\prime} 60.00^{\prime \prime}\right.$ N, 9147'59.99" E, $270 \mathrm{~km}$ long) is known as the gate way of hill tracts of South Eastern Bangladesh (Fig.1). It supports the biggest sea port of the country, the

*Author for corresponding: <maazadi@yahoo.com>, 2Department of Zoology, Govt. City College, Chattogram 4000, Bangladesh.

(C2020 Zoological Society of Bangladesh DOI: https://doi.org/10.3329/bjz.v48i2.52364 
Chattogram port, contributes a lion share in the national economy every year (Tk.2717.18 crore, plus 650 crore Taka FDR during 2016-17, personal communication). The Karnaphuli or Kaptai reservoir (68,800 ha) was created in 1961 by damming the River Karnaphuli at Kaptai point, to produce only hydropower (242 MW in 2016-17) of the country. Besides hydroelectricity, the reservoir also contributes a remarkable amount of freshwater fish yearly (13751 MT during 2018-19 year, BFDC 2019). There are five big tributaries of the River Karnaphuli, namely Myani, Chengi, Rainkhiang, Ichamati and Halda.

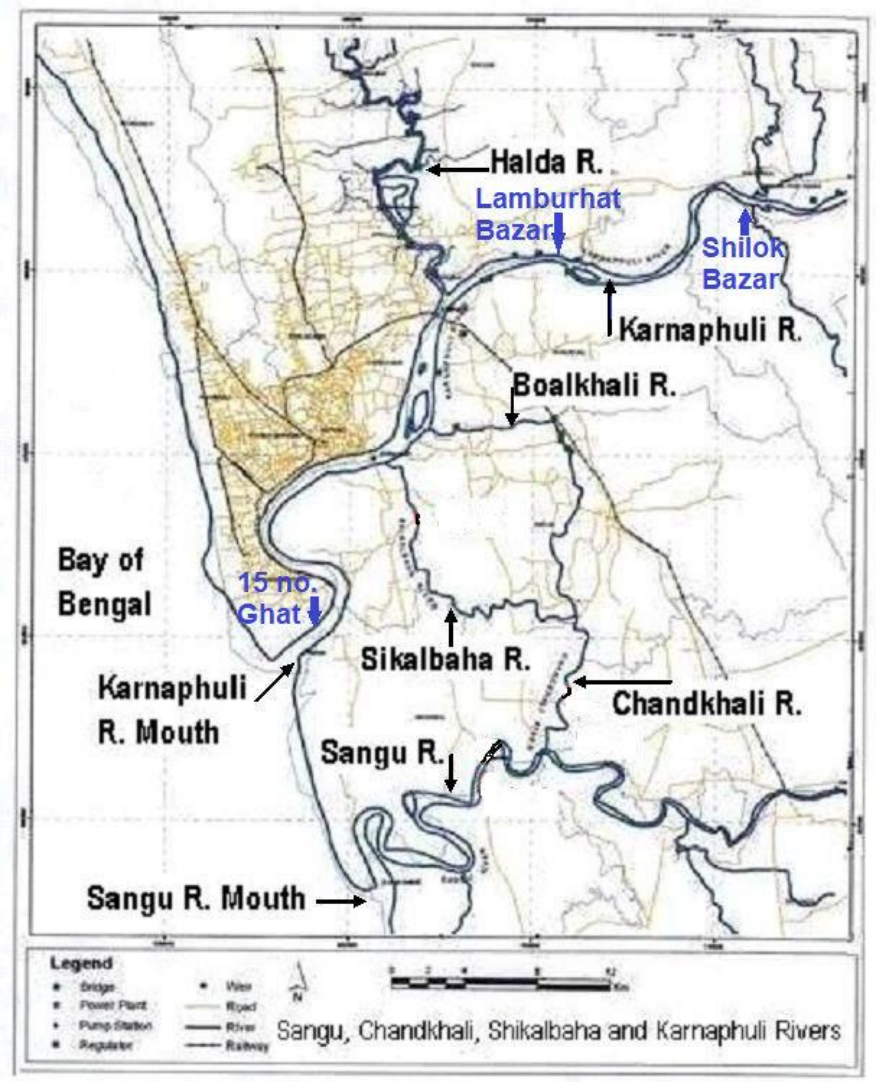

Fig. 1. Map showing the study area in the three linked rivers (Karnaphuli, Sikalbaha, \& Chandkhali) along with five interconnected rivers (Halda, Karnaphuli, Sikalbaha, Chandkhali and Sangu) of Chattogram river system.

Except Ichamati major carps breed and spawn during monsoon in other four tributaries of the river Karnaphuli (Azadi 2019, 1985). Egg collection and fry production of major carps is regularly practiced in Halda River. Amongst the other four tributaries, only from Myani River BFDC collects the major carp's eggs during monsoon and hatches the same in artificial hatching tank. Hatched 
fries are reared to fingerlings in the reservoir creeks and later released in the Kaptai lake. Most of the ethnic communities of Chittagong hill tracts are dependent on this river for their livelihood from very beginning of their settlement and make this river as a common cultural heritage. Sikalbaha and Chandkhali are the two important linked rivers which are also linked with the Sangu and Halda rivers via the River Karnaphuli, which facilitate the migration of major carps from the River Sangu to the River Halda during breeding season and also movement of other migratory fresh and estuarine fishes in these five interconnected rivers (Fig. 1). Isolated by physical barrier of land and sea from the Ganges-Brahmaputra river system the freshwater riverine and estuarine fish stock of the Karnaphuli-Sangu river system needed a distinctive attention for detailed taxonomic study.

During 2007 an amendment was made on "The Protection and Conservation of Fish Rules, 1985" for the protection and conservation of fish spawning in Halda River, as per regulations suggested by Khan and Azadi (2006). According to this regulation about $40 \mathrm{~km}$ waterways of the River Halda (Kalurghat Bridge to Nazirthat Bridge) was declared as fish sanctuary where fishing is prohibited throughout the year. Halda adjacent canals and rivers including the rivers Karnaphuli, Sangu, Sikalbaha and Chandkhali were declared as seasonal sanctuary where fishing is closed from February to July, and in the 16 tributaries of the River Halda from March to July. Operation of engine and mechanized boats are also prohibited in Halda Rver during prespawning, spawning and post spawning time (March to July) for facilitating migration of brood carps (Bangladesh Gazette 2007, 2010). If the regulations in the Bangladesh Gazette (2007 and 2010) are fully implemented, the disappeared fish species might be restored in those rivers.

Some works on freshwater ichthyofauna of different rivers and water bodies including Karnaphuli River estuary, Halda, and Sangu rivers of Chittagong were done by Ahmed and Hasan (1981), Tsai et al. (1981), Gafur and Bhuiyan (1983), Hafizuddin et al. (1989), Haroon et al. (1989), Alamgir et al. (1990), Halder et al. (1991), Hossain et al. (2007), Rashed-Un-Nabi et al. (2011), Azadi and Arshad-ul-Alam (2011, 2013, 2014), Arshad-Ul-Alam and Azadi (2017). Although ichthyofauna of Halda and Sangu rivers have been done (Azadi and Arshad-ul-Alam 2011, 2013, 2014) but no detailed works were found on Ichthyofauna of the three linked tidal rivers of Halda i.e. Karnaphuli, Chandkhali and Sikalbaha. The present investigation was carried out to find out the ichthyofauna of these three linked rivers along with their status. This work might be useful to protect and conserve the fish fauna of the three important rivers which connect the River Sangu with the River Halda. 


\section{MATERIAL AND METHODS}

For this study fish samples were collected from the three linked tidal rivers namely Karnaphuli, Sikalbaha and Chandkhali (Fig.1) at monthly intervals in fresh condition during May 2010 to April 2012 from the catch of 38 kinds of active fishing gears immediately after emptying the gears. Regular monthly field trips were made during this period for catch assessment using mechanized boat. Fish samples were also collected through irregular field visit during May 2012 to February 2020 upto Shilok Bazar, Rangunia at Karnaphuli River (22.44, 92.08) (17 km upstream from Lambur Hat Bazar) (Fig.1). Structured questioners and data sheets were used for catch assessment and sampling survey in the regular sampling area from the 15 No. Ghat near Karnaphuli mouth $(22.24,91.82)$ to Lambur Hat Bazar, Raozan $(35 \mathrm{~km}$ stretch of the Karnaphuli River) $(22.42,91.94)$ and entire Shikalbaha River (river mouth 22.32, 91.86 to Murali ghat 22.24, 91.96) and entire Chandkhali River (Murali Ghat 22.24, 91.96 to Keshua 22.18, 91.94), which connected the River Karnaphuli with the River Sangu (Fig 1). Photographs of fish samples were taken and colour pattern were noted in fresh condition. Specimens were preserved in $10 \%$ formaldehyde for detailed study later. Identification was made after reviewing external features and finer morphometric and meristic details with the help of works of Day (1889), Shafi and Quddus (1982), Rahman (2005) and IUCN (2000 and 2015). Regional threatened status was confirmed using IUCN (2015). Availability of the species was stated after analysis of catch assessment data. Classificatory scheme was mostly followed as proposed by Nelson et al. (2016). Accepted species name was confirmed from FishBase website.

\section{RESULTS AND DISCUSSION}

A total of 112 finfish species under 20 orders, 47 families and 90 genera and a total of 18 shellfish (16 prawns and 2 crabs) under 1 order, 3 families and 7 genera were identified from the rivers Karnaphuli, Sikalbaha and Chandkhali during ten years study period from May 2010 to February 2020. A list of finfish and shellfish species recorded from the Karnaphuli, Sikalbaha and Chandkhali rivers is given below (Table 1). The taxonomic list and systematic index of ichthyofauna with scientific name, local name, common name, habitat, regional Red List Category, threatened status as per IUCN Bangladesh Red List (2000, 2015) and abundance are presented in the list.

Taxonomic List of the recorded finfish and shellfish from the three studied linked rivers along with fishes previously recorded from the Sangu and Halda rivers are given in Table 1. 
Karnaphuli, Sikalbaha and Chandkhali are three linked rivers which are also linked with the Halda and Sangu rivers (Fig.1). In spite of being blocked by the Kaptai Dam, Karnaphuli River is still in touch with the Kaptai reservoir through the outlet (spill way) water, which is apparent during heavy monsoon shower when some fish species of Kaptai lake are seen in Halda and lower Karnaphuli rivers, which arrive through the discharged excess water of the lake through the spill ways. There is a variation of species and also in their number in different estuarine rivers. In advent of time due to over fishing, new techniques of fishing and fishing gears, climate change and human intervention, the number of species has not only varied in different rivers but also in the same river. Gafur and Bhuiyan (1983) documented 67 species of estuarine finfish from the Karnaphuli river estuary. Azadi and Arshad-Ul-Alam (2011) reported 83 species of finfish and 9 species of shellfish from Halda river. Azadi and ArshadUl-Alam (2014) reported 109 species of finfish and 18 species of shellfish from Sangu River (river mouth to Bandarban District Sadar). Arshad-Ul-Alam and Azadi (2017) first recorded a new carp species namely horned carp, Schismatorynchos nukta from hilly stream zone of upper Sangu River, Bangladesh. Ahmed and Hasan (1981), Hafizuddin et al. (1989) and Alamgir et al.(1990) reported 48, 58 and 72 species of finfish respectively from Kaptai lake. Halder et al. (1991) documented 64 finfish from the Feni River estuary, which included freshwater dependent 35, estuarine dependent freshwater 11, estuarine 7, estuarine dependent marine 9 and marine 2. Hossain et al. (2007) documented and illustrated 98 species of finfish, 23 species of prawn, 13 species of crab from the Naaf River. Rashed-Un-Nabi et al. (2011) recorded 45 estuarine species (35 finfish and 10 shrimps) from Bakhkhali River estuary. Pramanik et al. (2017) documented 107 finfish species from Meghna River. While Hossain et al. (2012) recorded 53 fin fish species from Meghna River estuary. Chowdhury et al. (2019) recorded 51 finfish species from Surma River, Sylhet Sadar, Bangladesh.

In the above-mentioned rivers maximum number of finfish species (110) was found in the river Meghna (Pramanik et al. 2017) and maximum number of shell fish (23) and crab species (13) in the River Naaf (Hossain et al. 2007), whereas minimum number of fin fish species (45) and shell fish species (10) were found in the estuarine River Bakhkhali (Rashed-Un-Nabi et al. 2011). In 

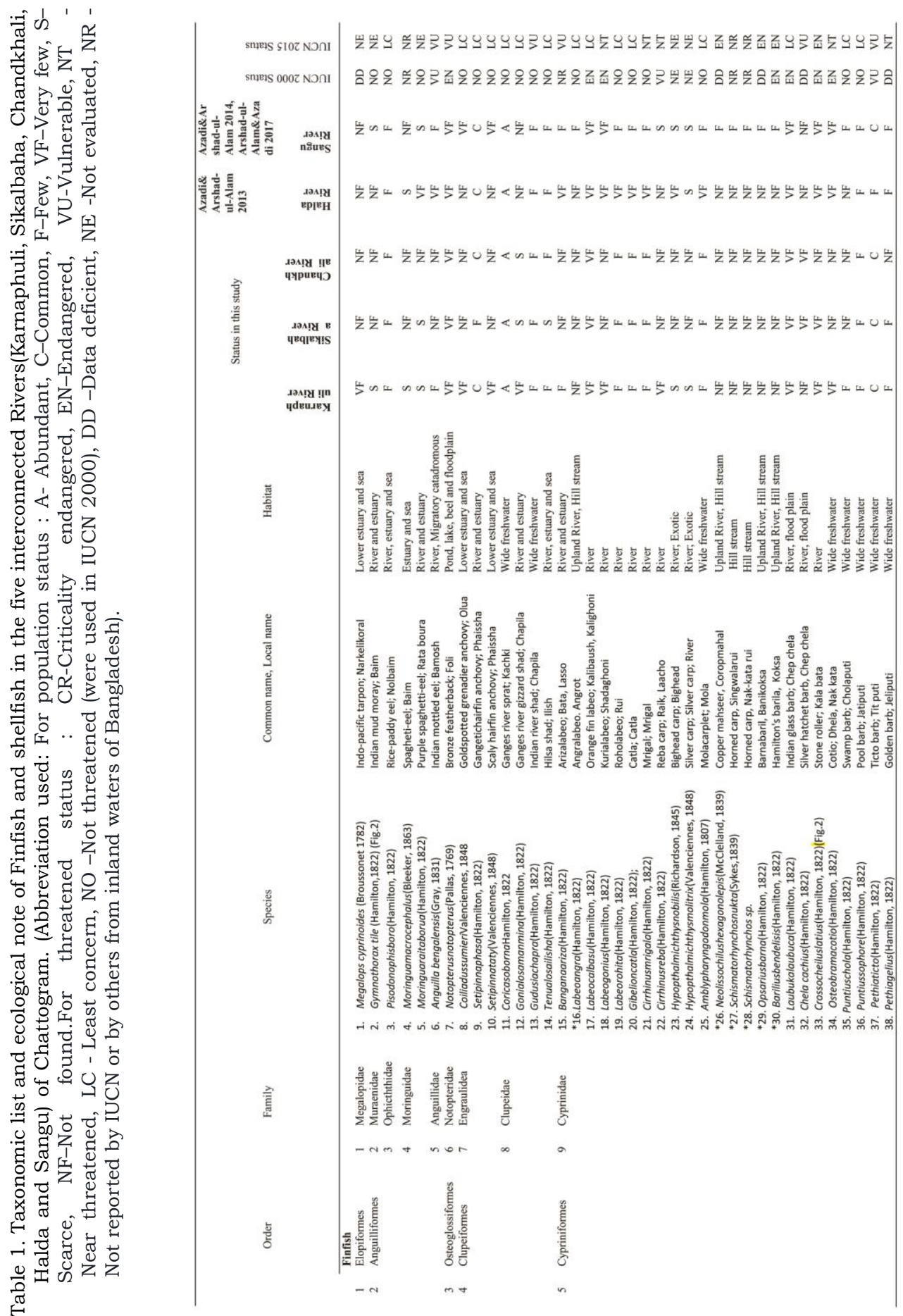







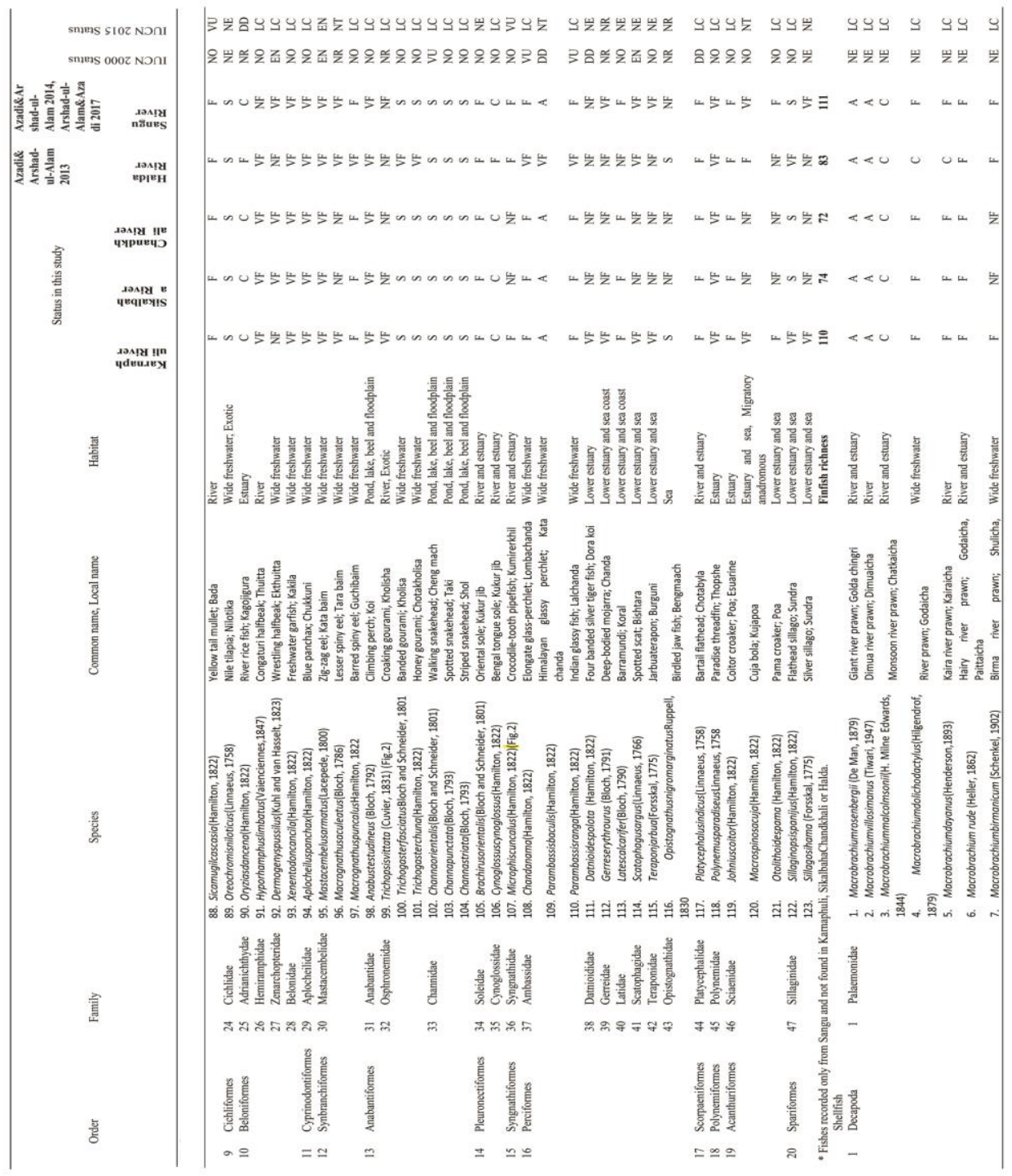




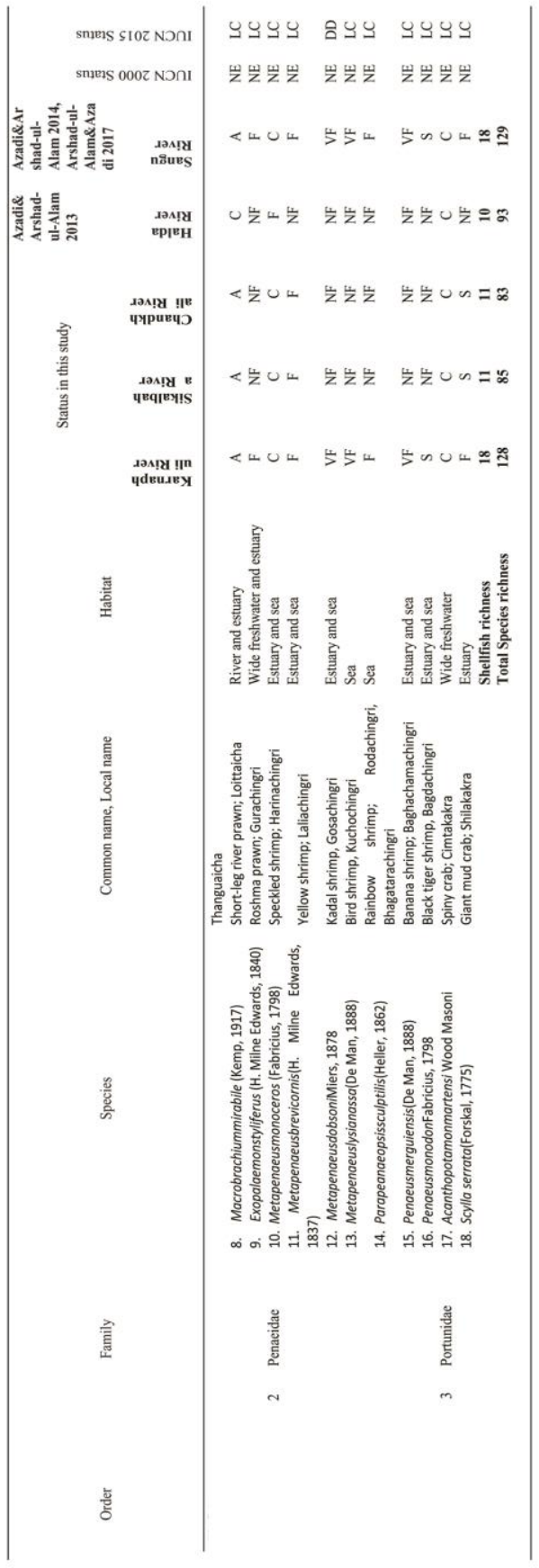


the present investigation a total of 130 species of ichthyofauna (112 finfish and 18 shellfish) were recorded from the three linked rivers i.e. Karnaphuli, Sikalbaha and Chandkhali. Among the three rivers highest number of finfish (110) and shellfish species (18) and altogether 128 ichthyofauna were recorded from the River Karnaphuli, while a total of 74 fin fish and 11 shellfish, altogether 85 ichthyofauna and 72 finfish and 11 shellfish, altogether 83 ichthyofauna species were recorded from Sikalbaha and Chandkhali rivers respectively. The variation in the recorded numbers of finfish and shellfish species in these three linked estuarine rivers was due to the variation in river size (length, width and depth) and total area of the rivers as well as habitat condition and also having chance of directly joining with the sea by the River Karnaphuli, which was also true for the above mentioned other rivers studied by different authors. In context of presence of finfish numbers, Karnaphuli (110) showed higher species density than lower Sangu (109) and Halda (83), but equals to the Meghna (110) while in context of shell fish numbers both rivers Karnaphuli (18) and Sangu (18) occupied the second position after the river Naff (23) but higher than the Halda (10), Sikalbaha (11) and Chandkhali (11). Number of Ichthyofauna in other two studied rivers (Sikalbaha and Chandkhali) was moderate but lower than the River Halda, Karnaphuli and Sangu.

In earlier edition of Threatened Animals of Bangladesh (IUCN Bangladesh 2000) ten fish species were evaluated as freshwater but in update edition of IUCN Bangladesh (2015) these fish species were considered as marine. These ten species are Megalops cyprinoides, Moringua raitaborua, Gymnothorax tile, Lates calcarifer, Scatophagus argus, Terapon jarbua, Paraapocryptes serperaster, Oxyurichthys microlepis, Polynemus paradiseus and Brachirus orientalis. Six species were not evaluated in either edition of IUCN Bangladesh 2000, or IUCN Bangladesh 2015, as they are marine exclusively. These are Moringua macrocephalus, Hexanematichthys sagor, Giuris margaritacea, Sillago sihama,Gerri's erythrourus and Opistognathus nigromarginatus, but they are occasional invaders in river. Four freshwater fish species not reported in IUCN Bangladesh 2000, but reported in IUCN Bangladesh 2015 are Bangana ariza (VU), Oryzias dancena (DD), Pseudapocryptes elongates (LC), and Macrognathus aculeatus (NT).

Under the genus Cirrhinus only Cirrhinus mrigala was reported from the Halda River (Azadi and Arshad-Ul-Alam 2013). Karnaphuli is enriched with another congeneric species, Cirrhinus reba. No specimen of Cirrhinus cirrhosus was found in the three studied rivers, which was also not reported from Sangu and other rivers of Chattogram (Azadi and Arshad-Ul-Alam 2014, Personal communication). Cirrhinus cirrhosus is characterized by two pairs of well- 
developed barbels, rostral pair is longer than maxillary barbel, Cirrhinus mrigala has rostral pairs only. It is noticeable that a single specimen of Cirrhinus cirrhosus (Fig.2) was collected by the present authors from Chowmuhani Arong (Arong is the local name of village market in Cumilla) of Devidwar Upazilla Sadar of Cumilla district. Although the seller primarily claimed it as Gomti river fish, but he did not ascertain whether it was collected from captured or cultured stock. In the present study, several attempts were taken to collect more Cirrhinus cirrhosus from different fish markets and fishermen of Chattogram and Devidwar and Muradnagar Upazilla but failed.

Rahman (2005) stated Cirrhinus mrigala as a synonym of Cirrhinus cirrhosus (p.140). Day (1878, 1889), Talwar and Jhingran (1991), Dahanukar (2010), (IUCN 2019), Rema Devi and Ali (2011), (IUCN 2019), Menon 2004 (IUCN 2019), Menon (1999) (Fishbase) and Roberts (1997) (Fishbase) described Cirrhinus mrigala and Cirrhinus cirrhosus as two distinct species with morphological differences and with different geographical distribution.

According to Day (1878, 1889), Talwar and Jhingran (1991), Goswami et al. (2012), FishBase and IUCN Red List (accessed on 24 March 2020) Cirrhinus mrigala is native of northern India, Pakistan and Bangladesh; however the native range of Cirrhinus cirrhosus is the Godavari, Krishna and Cauvery rivers of South India. Both the species have been introduced to other regions of India and many countries outside of India. In the present study the recorded Cirrhinus cirrhosus from Gomti river of Comilla may be introduced or invaded in Bangladesh river waters from Indian Tripura region or Barak river drainage.

Oryzias dancena was reported as data deficient (DD) in recent Redlist of Bangladesh (IUCN Bangladesh, 2015) although it might be considered as least concern (LC) as per guidelines for using the IUCN Red List categories and criteria (IUCN Standards Petitions Subcommittee 2014). In first edition of IUCN Bangladesh (2000) it was not reported and was first reported by Azadi and Arshad-Ul-Alam (2013) from the river Halda. This tiny fish was found common in the catch of enclosure net (locally called Ghera jal of $2 \mathrm{~mm}$ mesh) used in the Rivers Halda, Karnaphuli, Sangu and their tributaries (Azadi and Arshad-U1Alam 2014).

Laubuka laubuca was reported as endangered in IUCN Bangladesh (2000) and as least concern in IUCN Bangladesh (2015). This species was recorded as very rare in Halda and Sangu by the present authors (Azadi and Arshad-U1-Alam 2013, 2014).

Plotosus canius locally known as 'Gang magur' is a euryhaline species found mostly in estuary and coastal area and in this study it was recorded from the lower Karnaphuli near to Karnaphuli mouth estuary. Recently, present 
authors collected an individual of juvenile Plotosus canius from the electrofishing catch in the Remakri river, a remote hilly upstream tributary of Sangu river.

Trichopsis vittata reported as an unintentionally invaded ornamental fish (Norén et al. 2017) was recorded from Turag, Dhaleshwari and Titas rivers. It was recorded as abundant in Turag river but not found in southeastern Bangladesh (Chittagong division) during 2015 and northeastern Bangladesh

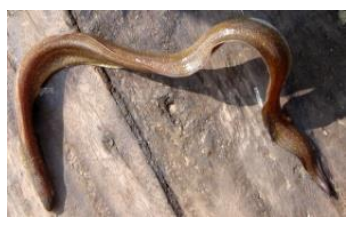

Gymnothorax tile Only in Karnaphuli

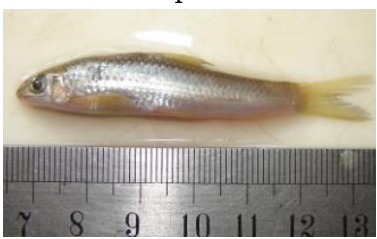

Crossocheilus latius in Karnaphuli \& Sikalbaha

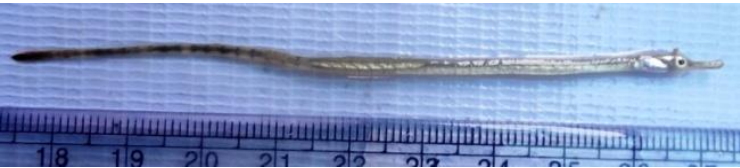

Microphis cuncalus in Karnaphuli

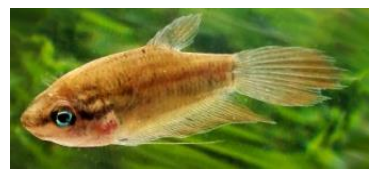

Trichopsis vittata in Karnaphuli

Plotosus canius in Karnaphuli and Sangu

Cirrhinus cirrhosus (Not found in Karnaphuli \& linked rivers)
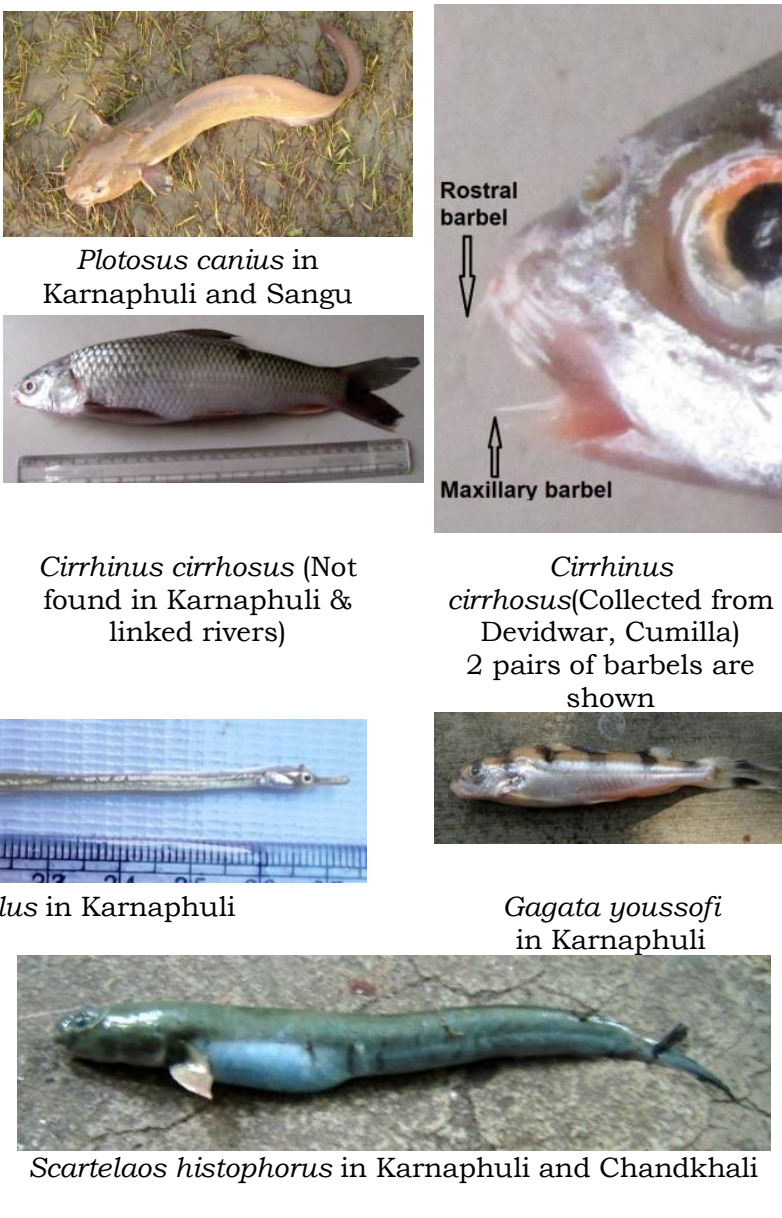

Scartelaos histophorus in Karnaphuli and Chandkhali



Cirrhinus cirrhosus(Collected from Devidwar, Cumilla)

2 pairs of barbels are shown

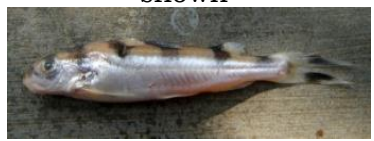

Gagata youssofi in Karnaphuli

Fig. 2. Photographs of some fishes found in studied rivers excluding Cirrhinus cirrhosus.

(Sylhet division) during 2016 (Norén et al. 2017). However, in recent survey during April 2018, considerable number of this species was found in Set-Bag net catch in Karnaphuli river, although no such specimen was found in previous 
eight years extensive survey. This species was also reported during 2017 from the hilly up stream of Chittagong University Campus (Azadi and Mandol 2017).

Out of 112 finfish species, 76 species and out of 18 shell fish species, 11 species were common in three linked rivers. However, 40 species of finfish and 7 species of shellfish were only found in the river Karnaphuli. Chela cachius and Dermogenys pussilus were not found in Karnaphuli river. There was no example of the recorded species being found only in Chandkahli or Sikalbaha rivers. It might be due to the quality of water, size of the rivers in respect of length, width, depth and total area of the studied rivers.

\section{CONCLUSION}

Out of the five linked rivers of Chattogram River system, ichthyofaunal study of two linked Rivers, Halda and Sangu (lower Sangu) have been done earlier (Azadi and Arshad-Ul-Alam 2013, 2014). With the study of three more linked rivers, Karnaphuli, Sikalbaha and Chandkhali, icthyofaunal study of five linked rivers has been completed. In this study a total of 130 ichthyofaunal species have been recorded from the three rivers, out of which 128 species (110 fin and 18 shell fish) were from the River Karnaphuli, 85 species (74 fin and 11 shell fish) were from the River Shikalbaha and 83 species (72 fin and 11 shell fish) were from the River Chandkhali. Ichthyofauna of other two linked rivers, Halda and Sangu were found to be 93 species (83 fin fish and 10 shell fish) and 127 species (109 fin fish and 18 shell fish) respectively (Azadi and Arshad-U1Alam 2013, 2014). Among the five linked rivers highest number of ichthyofaunal species were recorded from the River Karnaphuli (128) while second, third, fourth and fifth highest were recorded from the Rivers Sangu (127), Halda (93), Sikalbaha (85) and Chandkhali (83). This variation was due to different river size, length, depth and absence or presence of diversified habitat in different rivers. This study will be helpful to the policy makers, planers and researchers to protect, manage, conserve and for further study of the important fin and shell fishes of the five linked rivers of Chattogram.

Acknowledgement: This is a part of study conducted under the grants for advanced research in education entitled "Limnology, Hydrology and Fish and Fisheries of the River Halda and its four linked rivers (Sangu, Chandkhali, Sikalbaha and Karnaphuli)" sponsored by the Ministry of Education Bangladesh during 2010-2013. In this paper only ichthyofaunal part is included, conducted during the mentioned period and also personal continuation of the work up to 2020. 


\section{LITERATURE CITED}

AHMED, B. and HASAN, S. 1981. A checklist of the fishes of the Karnaphuli Reservoir. Bangladesh J. Zool. 9(1): 37- 40. and

ARSHAD-UL-ALAM, M. and AZADI, M. A. 2017. First record of horned carp Schismatorynchos nukta (Skyes, 1839) (Cypriniformes:Cyprinidae) from Bangladesh and its present status. $J$. biodivers.conserve. bioresour.manag. 3(1): 85-92.

AZADI, M.A. 2019. Advanced management and fish culture techniques to increase the fish Production in Kaptai lake. Key note paper presented in the workshop organized by Bangladesh Fisheries Development Corporation (BFDC), Ministry of Fisheries and Livestock on 5 September 2019 in the Conference Room of Bangladesh Agricultural Research Council, Farm gate, Dhaka.

AZADI, M.A. and MONDAL, K. 2017. Fin and shell fish diversity in relation to water quality in a hilly stream (Balukhali Chara) of Chittagong University campus. 20 th International Biennial Zoological Conf. and AGM, 2017, Zoological Society of Bangladesh and Department of Zoology, University of Dhaka, held on 9-10 December, 2017, Abstract no.77, page 85.

AZADI, M.A. and ARSHAD-UL-ALAM, M. 2014.Biodiversity and conservation of fin and shellfishes of the River Sangu, Bangladesh. In The IUCN Bangladesh.The Festschrift on the $50^{\text {th }}$ Anniversary of the IUCN Red List of threatened Species, Dhaka, Bangladesh. (ed. Khan. M.A.R). Page 67-74.

AZADI, M. A. and ARSHAD-UL-ALAM, M. 2013. Ichthyofauna of the river Halda. Bangladesh J. Zool. 41: 113-133.

AZADI, M.A. and ARSHAD-UL-ALAM, M. 2011. Diversity of Finfish and Shellfish of the River Halda with Notes on their Conservation. In Eivin Røskaft and David J. Chivers (Eds.), Proc.Internat.Conf.on Biodiversity-Present State, Problems and Prospects of its Conservation. Norwegian Center for International Cooperation in Education (SIU), NO 5809, Bergen, Norway.Tapir Academic Press, Trondheim, Norway. Page 92-102.

AZADI, M.A. 1985. Spawning of Commercial Freshwater Fish and Brackish and Marine water Shrimps of Bangladesh. Bgd.Fish. Inf. Bull. 2(2):1-74.

ALAMGIR, M., CHOWDHURY, S.H. and AHMED, A. S. M. 1990. New records of Ichthyofauna of lake Kaptai. Chittagong Univ. Stud., Part II,14(2):137-139.

BANGLADESH GAZETTE. 2007. Bangladesh Gazette, 15 May2007, Ministry of Fisheries and Livestock, SRO 75-Law/2006, Bangladesh.

BANGLADESH GAZETTE. 2010. Bangladesh Gazette, 14October 2010, Ministry of Fisheries and Livestock,SRO 345-Law/2010, Bangladesh.

BFDC. 2019. Annual Fish landing records of Kaptai lake, Bangladesh Fisheries Development Corporation (BFDC), Rangamati. Bangladesh.

CHOWDHURY, M. A., KARIM, M.A., RAHMAN, M.T., SHEFAT, S.H.T., RAHMAN, A. and HOSSAIN, M.A. 2019. Biodiversity Assessment of Indigenous Fish Species in the Surma River of Sylhet Sadar, Bangladesh. Punjab University Journal of Zoology 34(1): 73-77. 
DAHANUKAR, N. 2010. Cirrhinus mrigala. The IUCN Red List of Threatened Species 2010: e.T166146A6183216. https://dx.doi.org/10.2305/IUCN.UK.2010-

4.RLTS.T166146A6183216.en. Downloaded on 24 March 2020.

DAY, F.1878. The fishes of India; being a natural history of the fishes known to inhabit the seas and fresh waters of India, Burma, and Ceylon.

DAY, F.1889.The fauna of British India Including Ceylon and Burma: Fishes Vol. I, pp. 548, and Vol. II, pp. 509. Toylor and Francis, London.

FISH BASE.https://www.fishbase.in/search.php, Accessed on 24/03/2020.

GAFUR, M. A. and BHUIYAN, A.L. 1983. Successional occurrence of the fish-fauna of the Karnaphuli river estuary in response to salinity. Chittagong Univ. stud., Part II, 17(2): 69-77.

GOSWAMI, U. C., BASISTHA, S.K., D. BORA, D., SHYAMKUMAR, K., SAIKIA, B. and CHANGSAN, K. 2012. Fish diversity of North East India, inclusive of the Himalayan and Indo Burma biodiversity hotspots zones: A checklist on their taxonomic status, economic importance, geographical distribution, present status and prevailing threats. International Journal of Biodiversity and Conservation Vol. 4(15), pp. 592-613. http://www.academicjournals.org/IJBC DOI: 10.5897/IJBC11.228 ISSN 2141-243X.

HAFIZUDDIN, A.K.M., MAHMOOD, N. and AZADI, M.A.1989. An addition to the Ichthyofauna of Kaptai Lake.Bangladesh J. Zool. 17(1): 29-33.

HALDER, G. C., HAROON, A.K.Y., KHAN, M.A.A. and CHU-FA-TSAI. 1991. Fish nursery ground investigation of the Feni River Estuary (Bangladesh) with refference to the impacts of the irrigation flood control project. Bangladesh J. Zool. 91(1):85-94.

HAROON, A.K.Y., KHAN, A.A., HALDER, G.C. and RAINBOTH, W.J. 1989. A checklist of the fish and prawn fauna of the Muhuri irrigation project and surrounding region. Bangladesh J. Zool. 17(1):19-28.

HOSSAIN, M. S., DAS, N.G.and CHOWDHURY, M.S.N. 2007. Fisheries management of the Naaf river. Coastal and Ocean Research Group of Bangladesh, Institute of Marine Science and Fisheries, University of Chittagong, 267pp.

HOSSAIN M. S., DAS, N.G., SARKAR, S. and RAHAMAN, M.Z.. 2012. Fish diversity and habitat relationship with environmental variables at Meghna river estuary, Bangladesh. Egyptian Journal of Aquatic Research, 38, 213-226.

IUCN 2019. The IUCN Red List of Threatened Species. Version 2019-2. Downloaded on 23 July 2019.

IUCN BANGLADESH. 2000. Red list of threatened animals of Bangladesh. IUCN- The World Conservation Union. Xii $+54 \mathrm{pp}$.

IUCN (Standards Petitions Subcommittee). 2014. Guidelines for using the IUCN Red List categories and criteria, Version 11, Prepared by Standards and Petitions Subcommittee.

IUCN BANGLADESH. 2015. Red List of Bangladesh: Freshwater Fishes. Vol.5. International Union for conservation of Nature, Bangladesh Country office, Dhaka, Bangladesh.360 pp. 
KHAN, S. and AZADI, M.A. 2006. Studies and management strategies to revive and sustain the fisheries in the River Halda, Research Project.MoFL and WorldFish Centre.

MENON, A.G.K. 2004. Threatened Fishes of India and their Conservation,:1-170 (Published by the Director, Zool. Surv. India).

MENON, A.G.K., 1999. Check list - fresh water fishes of India. Rec. Zool. Surv. India, Misc. Publ., Occas. Pap. No. 175, 366 p. (FishBase, Ref. 41236)

NELSON, J.S., Grande, T.C., WILSON, M.V.H. 2016.Fishes of the World.5 th Edition, Jhon Wiley and Sons, New York.523 pp.

NOREN, M., KULLANDER, S.O., M.M. RAHMAN, M.M., MOLLAH, A.R. 2017. First records of Croaking Gourami, Trichopsis vittata (Cuvier, 1831) (Teleostei: Osphronemidae), from Myanmar and Bangladesh. Check List 13 (4): 81-85. https://doi.org/10.15560/13.4.81

PRAMANIK, M. M. H., HASAN, M.M., BISSHAS, S., HOSSAIN, A.B.MA. and BISWAS,

T.K. 2017. Fish biodiversity and their present conservation status in the Meghna river of Bangladesh. International Journal of Fisheries and Aquatic Studies.5(1): 446-455.

RAHMAN, A.K.A. 2005. Freshwater Fishes of Bangladesh. 2nd ed., Zool. Soc. Bangladesh, Dhaka, Bangladesh.394 pp.

RASHED-UN-NABI, MAMUN, M.A., ULLAH, H.and MUSTAFA, M.G. 2011. Temporal and special distribution of fish and shrimp assemblage in the Bakkhali river estuary of Bangladesh in relation to water quality parameter. Marine Biology Research.7: 436-452.

REMA DEVI, K.R. and Ali, A. 2011. Cirrhinus cirrhosus. The IUCN Red List of Threatened Species 2011:e.T166531A6230103. https://dx.doi.org/10.2305/IUCN.UK.2011-

1.RLTS.T166531A6230103.en. Downloaded on 24 March 2020.

ROBERTS, T.R., 1997. Systematic revision of the tropical Asian labeon cyprinid fish genus Cirrhinus, with descriptions of new species and biological observations on C. lobatus. Nat. Hist. Bull. Siam Soc. 45:171-203. (FishBase, Ref. 33488)

SHAFI, M.and QUDDUS, M.M.A.. 1982. Bangladesher Matsho Sampad (Fisheries of Bangladesh, (inBengali).Bangla Academy, Dacca, Bangladesh.444 pp.

TALWAR, P.K. and JHINGRAN, A.G. 1991. Inland Fishes of India and Adjacent Countries. Oxford-IBH Publishing Co. Pvt. Ltd., New Delhi.

TSAI, C.F, ISLAM, M.N., KARIM, M.R. and RAHMAN, K.U.M.S. 1981. Spawning of major carps in the lower Halda River, Bangladesh. Estuaries 4(2): 127-138.

(Manuscript received on 27 May, 2020 revised on 15 December, 2020) 